\title{
THE CARE AND ASSISTANCE PROVIDED FOR POLISH CHILD REFUGEES IN BARCELONA IN THE IMMEDIATE POST-WWII PERIOD ${ }^{1}$
}

\author{
Paweł Sękowski \\ http://orcid.org/0000-0003-4743-7990 \\ Jagiellonian University, Kraków
}

\begin{abstract}
This paper examines the care and protection provided for Polish children living in the Polish centre in Barcelona between 1946 and 1956. The majority of these children originated from the Polish Silesia and the Łódź regions, which had been incorporated into the Reich, and most of them had been kidnapped by the Nazis during the War with the aim of Germanizing them. At the end of the conflict, they were living in Displaced Persons camps, mainly in Austria, where they were found by officers of the 2nd Polish Corps. This text provides an analysis of the care and support these Polish children received in Barcelona, both from the Polish Government-in-exile and from the international community. Particular emphasis is placed on the care provided for these children from the International Refugee Organization (IRO). The role of the Spanish government (at that time under the authoritarian rule of Francisco Franco) in helping these children is also discussed. In addition, the 59 charges of the Polish centre in Barcelona who applied for IRO assistance in 1950 are analysed on the basis of documents from the IRO archives deposited in Archives Nationales, in France which have been used for the first time in research on this topic.

Keywords: Polish Children in Barcelona, Displaced Persons, refugees, unaccompanied children, International Refugee Organization (IRO), American Polish War Relief (APWR), Relief Society for Poles, Poles in Spain, post-war period, resettlement, repatriation, tracing service.
\end{abstract}

The aim of this article was to investigate the issue of the care and assistance provided for the Polish children residing at the Polish centre in Barcelona between 1946 and 1956. This group initially comprised around 100 children found by officers of the

1 This paper was realized within the frame of the project Sonata 10 of the National Science Center NCN: Activity of the International Refugee Organization in the post-war Europe: The case of the caring action towards Polish displaced persons and refugees, 1947-1951, Reference no. UMO-2015/19/D/ HS3/02361 (for the years 2016-2020). 
$2^{\text {nd }}$ Polish Corps in Displaced Persons camps, principally in Austria, but also in a few cases also in Germany, France and Italy. Following the repatriation of some of these children to Poland and the emigration of others to the USA, their number gradually declined until the centre was finally closed in 1956.

These children, the majority of whom originated from the Polish Silesia and Łódź regions that had been incorporated into the Reich, had mostly been kidnapped by the Germans during the World War II as part of the Lebensborn programme. The main goal of Lebensborn was to boost the birth rate of "Aryan children" through the practise of impregnating women and having them give birth in secret to children in centres located in the Reich and occupied countries. However, the programme also involved kidnapping children from occupied territories for the purpose of Germanizing them. ${ }^{2}$

The unique, dramatic, but ultimately happy story told here is not very well known. Furthermore, it is a topic that very few historians have tackled. Most of the information on the fate of the Polish children in Barcelona comes from brief references to them contained in broader studies on other topics. The issue addressed in this paper was only brought to the attention of a wider public in 2008 following a newspaper article published in the Spanish daily El Pais by José Luis Barbería, which caused a stir not only throughout Catalonia, but also in Poland and among Poles abroad. ${ }^{3}$ In the same year, a richly illustrated history of Poles in Barcelona, with a particular emphasis on the experiences of the children from the Polish centre in Barcelona after the World War II, appeared in a trilingual edition in Catalan, in Spanish and in Polish. ${ }^{4}$ The latter book, penned by Marek Pernal, remains to date the best contribution to our knowledge on the subject. It is a reliable and very detailed description of the arrival and experiences of Polish children in Barcelona between 1946 and 1956, as well as of their departure from Spain. However, the author sheds no light at all on the care and assistance provided by the international community for these children. ${ }^{5}$

2 See i.a.: C. Clay, M. Leapman, Master Race: The Lebensborn Experiment in Nazi Germany, London 1995; G. Lilienthal, Der „Lebensborn e.V.": Ein Instrument nationalsozialisticher Rassenpolitik, Frankfurt am Main 2003; T. Bryant, Himmlers Kinder: Zur Geschichte der SS-Organisation „Lebensborn e.V.", Wiesbaden 2011; R. Hrabar, „Lebensborn”, czyli źródło życia, Katowice 1975; E. Karpińska-Morek, A. Waś-Turecka, M. Sieradzka, A. Wróblewski, T. Majta, M. Drzonek, „,Teraz jesteście Niemcami”. Wstrzasajace losy zrabowanych polskich dzieci, Kraków 2018.

3 The mentioned article was: J. L. Barbería, "Los niños que Hitler robó. Huérfanos de la barbarie nazi," El País, 11 May 2008.

4 Polonesos a Barcelona: Un munt d'històries: l'acolliment de la ciutat als nens robats pels nazis, 1946-1956 = Polacos en Barcelona, un montón de historias: la acogida de la ciudad a los niños robados por los nazis, 1946-1956 = Polacy w Barcelonie, album historii. Polskie dzieci ukradzione przez nazistów pod opieka miasta, 1946-1956, Barcelona 2008. An important role in the work on finding archival documents about the Polish children from Barcelona, in the archives of the Polish Institute and Sikorski Museum in London, was played by Jadwiga Kowalska, deputy manager of these archives.

5 M. Pernal, Barcelona, bon port: Història del cente d'acollida per a infants polonesos, 1946-1956 = Barcelona, buen Puerto: Historia del centro de acogida para niños polacos, 1946-1956 = Przystań Barcelona. Placówka opiekuńcza dla dzieci polskich w stolicy Katalonii w latach 1946-1956 [in:] Polonesos a Barcelona, pp. 94-145 (in Catalan); 148-163 (in Spanish); 166-183 (in Polish). There is also an article in English about this topic: A. Gruzińska, "Children Remember the War: Polish Children in 
The present text aims to describe and analyse the history of these child refugees in terms of the support they received from the Government-in-exile of the Republic of Poland in London - which at that time refused to acknowledge the existence of the rival, communist-dominated regime in the Republic of Poland (later the People's Republic of Poland) in Warsaw, which had just been recognized by nearly all countries in the world as well as by the United Nations. The paper also investigates the aid provided by the international community, primarily via the International Refugee Organization (IRO). The participation of the Spanish government (then under the authoritarian rule of Francisco Franco) is also discussed.

The paper is based on original research on IRO archival documents that are stored in the Archives Nationales in Pierrefitte-sur-Seine, near Paris following the IRO's final dissolution in 1952. It also makes use of the archives of the Polish Institute and Sikorski Museum in London, where the records of the former Polish government-inexile are kept. ${ }^{6}$

The materials that the author found in the IRO archives, including personal questionnaires - applications for IRO assistance, in this case applications concerning children from the Polish centre in Barcelona - are used here for the first time as a source for studying the care and assistance provided for Polish children in Barcelona in the years immediately following the World War II.

\section{POLISH REFUGEES IN SPAIN IN THE IMMEDIATE POST-WAR PERIOD AND THE CARE AND ASSISTANCE PROVIDED FOR THEM}

In the first years following the World War II more than 200 Polish refugees in Spain benefited from material aid provided by the British Interim Treasury Committee for Polish Question (ITC). The ITC constituted a continuation of the activities of

Barcelona, 1946-1956,” The Polish Review 2010, vol. 55(1), pp. 111-122. However, that interesting text brings new information - comparing to the text of Marek Pernal - only about accommodation conditions and the everyday life of the Polish children in Barcelona. Indeed, the purpose of that short text, with the addition of photographs, was to draw attention - for the first time - to the history of the Polish children from Barcelona to English-speaking readers. At more that is the contribution of considerable importance, because the Author of the article - Aleksandra Gruzińska, Emeritus Professor in the School of International Letters and Cultures at Arizona State University, USA, herself is a former member of the group of the Polish children from Barcelona.

${ }_{6}$ The Polish government-in-exile had its headquarters in London since the World War II. Between the end of June and July 1945, most of the world, including the United Kingdom, withdrew his recognition of the Polish government-in exile and at the same time recognized the Provisional Government of National Unity, created in June 1945 in Warsaw, dominated by communists. The Polish government-inexile, based in London, as well as the successive presidents of the Republic of Poland-in-exile, functioned as a center of progressively only nominal significance until December 1990, when Lech Wałesa became the first president of the Republic of Poland elected by the people after the decline of real socialism. 
the Polish émigré Ministry of Labour and Social Welfare after the British authorities withdrew their recognition of the Polish Government-in-exile on 5 July 1945. ${ }^{7}$

Some of these refugees were subsequently repatriated to Poland, while others found in Spain permanent employment. Furthermore, a fresh influx of Polish refugees arrived in Spain just after the war, entering the country illegally via the Pyrenees. ${ }^{8}$ They had no desire to return to Poland and preferred for some reason to reside in Spain rather than in France or any other European country. In 1947 more than 100 Polish adult refugees and 43 Polish students in Spain were the beneficiaries of both international protection as well as assistance from the main aid organisation subordinate to the Polish government-in-exile (established in London) - the Relief Society for Poles (RSFP). To this total should be added a number of Ukrainian stateless persons - ex-Polish citizens from Eastern Galicia - who in December 1946 had been placed under the protection of the International Committee of the Red Cross. In addition, there were another 300 other Polish citizens living in Spain at that time, mainly near Madrid and Barcelona. ${ }^{9}$

Up until the end of 1946 the welfare of Polish refugees was the responsibility of both the Polish Government-in-exile in London and the above-mentioned ITC, which was a special-purpose agency of the British government. The ITC had its own representation in Spain through which it provided material aid. However, on 31 December 1946 the ITC closed down its operations in Spain.

Following the dissolution of the ITC, on 1 February 1947 the task of managing and allocating financial aid to Polish refugees in Spain was taken on by a specialized agency of the international community acting in collaboration with voluntary organizations - the Intergovernmental Committee on Refugees (IGCR) in Madrid and the office of the American Joint Distribution Committee (The Joint) in Barcelona. In January 1947, financial aid came from the remaining ITC funds, but this expenditure was later reimbursed by the IGCR. ${ }^{10}$

The entire relief effort on the Polish side was overseen by the RSFP, under whose name the former Polish Red Cross now operated. The Polish Red Cross in London, then RSFP refused to acknowledge the Provisional Government of National Unity established in June 1945 in Warsaw, and continued to recognize the authority of the Polish Government-in-exile. In 1947 RSFP's organisation in Spain comprised a na-

7 R. Habielski, Życie spoleczne i kulturalne emigracji, Warszawa 1999, p. 56.

8 Archives of the Polish Institute and Sikorski Museum in London (PISM), Embassy of the Republic of Poland in London - Political reports of Polish diplomatic offices (A.12.52)/12f, "Polish citizens' issues in Spain" - Report of Józef Potocki, Polish chargé d'affaires in Madrid, Madrid, 4 January 1947, sheet 23 (in Polish).

9 PISM, Inner Cabinet [Prezydium Rady Ministrów], Eaton Place (PRM.E)/135, Report on the Relief Society for Poles activities outside Great Britain in 1947, London, 15 May 1948, p. 57 (in Polish).

10 Archives Nationales - Site de Pierrefitte sur Seine (AN), Archives of the International Refugee Organization (AJ/43)/79, Memorandum of Robert J. Rossborough, IGCR: "Polish refugees in Spain and Portugal," 16 January 1947. 
tional representative, his deputy and a representative in Barcelona. The following year, the RSFP's staff in Spain was increased to four. ${ }^{11}$

Obviously, the help provided by Polish émigré organizations, including the Polish government -in-exile, was far from sufficient.

Due to the paucity of both financial and technical resources, over time international organizations - that had reformed after the humanitarian catastrophe of the World War II - became the main institutions providing aid, in particular material aid, for Polish refugees in Spain. International organizations were also responsible for organising the emigration of Polish refugees from Spain.

In the second half of the 1940s, international organizations began to play an increasingly important role in the welfare of Polish refugees not only in Spain, but in Europe as a whole, indeed all over the world. This was the case both with IGCR and United Nations Relief and Rehabilitation Administration (UNRRA) and their legal successor: IRO.

On 1 July 1947 the IRO took over the responsibilities of the former UNRRA and IGCR. In 1948 the total number of Poles receiving aid from international community in Spain comprised 100 refugees placed under the protection of the IRO and 62 illegal refugees interned in Spanish prisons and camps (after having illegally crossed the French-Spanish border during or just after the World War II). Some of these were under IRO protection and waiting to be resettled outside Spain. ${ }^{12}$ Meanwhile, the total number of Polish refugee students receiving aid from the RSFP in Spain had fallen to 28 by $1949 .{ }^{13}$

The IRO, which began to operate in Europe in mid-1947, did not maintain a separate mission in Spain. Its work was realized by American voluntary societies, such as The Joint, mentioned above, and the National Catholic Welfare Conference (NCWC). ${ }^{14}$

After The Joint closed its Madrid office on 1 July 1950, Mr. Samuel Sequerra, who was the head of The Joint's Barcelona office, took charge of all Spanish operations, not only those of The Joint but also those of the IRO. ${ }^{15}$

11 PISM, A.12.52/12f, "Polish citizens' issues in Spain," sheet 23; PISM, PRM.E/135, Report on the Relief Society for Poles activities outside Great Britain in 1947, pp. 57, 61; PISM, PRM.E/135, Report on the Relief Society for Poles activities outside Great Britain in 1948, London, 15 April 1949, p. 44 (in Polish).

12 PISM, PRM.E/135, Report on the Relief Society for Poles activities outside Great Britain in 1948, pp. 42-43.

13 Bibliothèque polonaise de Paris (BPP), Mieczysław Biesiekierski Collection, provisional reference code: 3, Report on the Relief Society for Poles activities in 1949, London 1950, p. 25, sheet 135 (in Polish).

14 L. W. Holborn, The International Refugee Organization: A Specialized Agency of the United Nations: Its History and Work, London-New York-Toronto 1956, p. 156.

$15 \mathrm{AN}, \mathrm{AJ} / 43 / 501$, Inter-Office Memorandum from Thomas Jamieson to Peter Jacobsen, Assistant Director-General of IRO in charge of operations, 23 January 1951, p. 2. 


\section{THE SPECIAL CASE OF POLISH CHILDREN IN BARCELONA AND THE PROTECTION PROVIDED FOR THEM}

A completely separate group comprising more than 100 Polish children was brought to Spain from Austria and Germany in 1946. This group consisted mainly of children kidnapped during the World War II by Nazi Germans for the purpose of "Germanizing" them within the framework of the Lebensborn programme. The majority of these children had blond hair, blue eyes and a "typically Aryan" appearance. It is also believed that some of them may have been conceived as a result of forced sexual relations between selected Polish women and German officers, which was another aspect of Lebensborn. ${ }^{16}$

Those children were discovered by officers of the Polish $2^{\text {nd }}$ Corps in camps established for Displaced Persons in those zones of Germany and Austria occupied by the Western Allies. The relocation of Polish children to Spain was overseen by the Delegation of RSFP to the Polish $2^{\text {nd }}$ Corps, in conjunction with the Polish Legation (representing the Polish government-in-exile) in Madrid. It was through the endeavours of General Władysław Anders, commander-in-chief of the Polish $2^{\text {nd }}$ Corps, that these Polish children were invited by the Spanish government to Barcelona. ${ }^{17}$

The first transport of 35 children, aged between 6 and 16, arrived in Barcelona from the Displaced Persons Camp in Salzburg on 24 April 1946. The second transport, comprising 77 children, reached Barcelona on 19 June 1946. The third and final transport with 13 children completed the journey on 16 October 1946. All three transports departed from Italy where the children had previously been transferred by their Polish guardians. ${ }^{18}$

Twenty-four children left Barcelona before the end of 1946, either because they were now above the age limit or because family members had quickly been found in Poland during that year. Eventually, the number of children in the Polish centre stabilized at $101-67$ boys and 34 girls, aged 2 to 18 years. ${ }^{19}$

The reason why Polish units still loyal to the Polish government-in-exile chose Spain as a temporary home for these children was simple: at that time, Franco's authoritarian regime was one of the few governments in the world that did not recognize the Provisional Government of National Unity in Warsaw.

16 J. L. Barbería, "Los niños que Hitler robó."

17 J. A. Radomski, Demobilizacja Polskich Sit Zbrojnych na Zachodzie w latach 1945-1951, Kraków 2009, p. 141; A. Dworski, "Hiszpania" [in:] Akcja niepodlegtościowa na terenie międzynarodowym, 1945-1990, ed. T. Piesakowski, Londyn 1999, p. 342; PISM, PRM.E/135, Report on the Relief Society for Poles activities outside Great Britain in 1947, p. 57.

18 Nens polonesos que van viure els anys 1946-1956 a Barcelona = Niños polacos que vivían durante los años 1946-1956 en Barcelona = Dzieci polskie przebywajace w latach 1946-1956 w Barcelonie [in:] Polonsesos a Barcelona, pp. 184-188; M. Pernal, Barcelona, bon port, pp. 108, 113-114, 121 (in Catalan); 151, 153, 155 (in Spanish); 169, 172, 175 (in Polish).

19 Ibid., p. 122 (in Catalan); 155 (in Spanish); 175 (in Polish). 
Polish émigré activists wanted to counteract the risk of the children being repatriated to Poland against their will, especially in cases where a child had no living relatives in Poland. Hence, the Spanish government guaranteed that the local authorities in Barcelona would adopt a favourable attitude towards the residency of the children in the Polish centre. ${ }^{20}$

From the very beginning of its activities in Barcelona, the American Polish War Relief (APWR) and its European representative based in Geneva - Florian Piskorski - played a very prominent role in transferring Polish children to the Catalan capital and providing them with aid and protection during their time there. The APWR was an agency created by the American Polish Council on 1 September 1939 for the purpose of providing help to Polish victims of the World War II.

The Polish child refugee centre in Barcelona also constituted a special case with regard to its sources of funding. At the beginning of 1947, the costs of caring for the 101 children at the centre were being covered by the Spanish authorities and the Spanish Red Cross. However, the teaching staff were remunerated by the Polish government-in-exile and supervised by the Polish Legation in Madrid. ${ }^{21}$

During this period international organisations gradually began to assume responsibility for Polish refugees in Europe, including the Polish children in Barcelona. Since the IRO set up operations in Spain, its tasks in Barcelona were performed exclusively by The Joint. ${ }^{22}$ IRO support for the Polish children in Barcelona primarily took the form of assisting in their efforts to emigrate to other countries. This was because the IRO was the sole organization authorized to arrange overseas resettlement.

Since these young refugees first arrived in in Spain, the Polish centre in Barcelona was headed by Wanda Morbitzer-Tozer, who at the same time was also secretary to the Honorary Consul of Poland in Barcelona Eduardo Rodón y Blasa. The Polish children found in the territories occupied by the Allies had been greatly traumatised by their experiences. Many of them had at some point even been forbidden to speak Polish and were transferred from one orphanage to another. In the final stages of the war some had been abandoned and some of them had hidden in woods and forests.

In notes made at the time by Wanda Morbitzer-Tozer and kept by her daughter Cristina Tozer who currently lives in Madrid, we read: "They did not want to go with the Poles they had heard so many horrible things about from their German families, and it was necessary to use force to take them from there; they defended themselves by biting and kicking their saviors. Only sometimes did music, Polish lullabies or carols manage to penetrate their closed fields of memory and spark their memories." Elsewhere, Morbitzer-Tozer wrote: "They have developed a survival instinct resulting from residing in a harmful or hostile environment, they are leery, arrogant and

20 Spain recognized the Polish Government-in-exile as the legitimate Polish authority until 1968. It was recognized longer only by the Vatican - in fact until 1972. See: K. Tarka, Emigracyjna dyplomacja. Polityka zagraniczna Rząu RP na uchodźstwie, 1945-1990, Warszawa 2003, passim.

21 PISM, A.12.52/12f, "Polish citizens' issues in Spain," sheet 23.

22 L. W. Holborn, The International Refugee Organization, p. 157. 
selfish. Older girls, Germanized to a greater extent, are surly, disobedient and mouthy; they set a bad example for younger children and make them rebel." ${ }^{23}$

At the time of their arrival in Barcelona, in 1946, the children ranged in age between 2 and 18. Their final number at the end of 1946 was, as has already been mentioned, 101. Initially, the children were accommodated on Anglia Street, in Bonanova district, in a former detention center of the People's Front, that had been subsequently adapted by the official Frankist charitable organization Auxilio Social for the needs of a children's shelter. They were later relocated to a shelter in the Vallcarca neighbourhood in the same district.

The Polish children learned Polish once more and attended a primary school in Polish. Some attended vocational schools in Spanish. They also attended religion classes. Thanks to the Polish centre, the children came into contact once more with the culture of their country of origin. ${ }^{24}$

As regards their general education, during the 1950-1951 school year the girls were divided up between the following institutions: the Polish school in Vallcarca, the Institut Santa Madrona college of nursing, and the Escuela Profesional para la Mujer de la Diputacion de Barcelona vocational school (not including those girls already working). In turn, the boys were divided up between the following institutions: Escuela del Trabajo, Escuela Massana (an industrial and art school) and the International College, not counting boys already working. ${ }^{25}$ Józef Tyszka, counsellor of the Polish Legation in Madrid, reported in in 1950 (and thus a few years after the children's arrival in Spain), that he was particularly impressed by the Polish girls in Barcelona - "they learn well, and their vocational training is also going well." This was "in contrast to the boys who nearly all dropped out of vocational school because of language difficulties or because the educational standards in the school were too highly theoretical, and they have to be satisfied with apprenticeships in ateliers and factories." 26

Especially admirable was the commitment and zeal of Mrs. Wanda Morbitzer-Tozer, the head of the Polish centre, who devoted a lot of her time, work and own money to helping the Polish children.

The plight of the Polish children in Barcelona was addressed at a special meeting held at the IRO headquarters in Geneva on 9 December 1948. The IRO had only become aware of the existence of these young refugees just a few months earlier. The attendees of the meeting agreed that the Polish State had jurisdiction over those chil-

23 J. L. Barbería, "Los niños que Hitler robó.”; idem, Dzieci ukradzione przez Hitlera - „El País”, 11/05/2008 [in:] Polonesos a Barcelona, p. 29 - translation from Polish by P.S.

$24 \mathrm{AN}, \mathrm{AJ} / 43 / 501$, Content of 48 applications for IRO assistance of children applying for overseas resettlement, 22 June 1950; AN, AJ/43/310, Content of 11 applications for IRO assistance of children applying for repatriation, 28 April 1950 and AN, AJ/43/501, Content of 11 renewed applications for IRO assistance of the same 11 children applying for repatriation, 9 June 1950; J. L. Barbería, "Los niños que Hitler robó"; idem, Dzieci ukradzione przez Hitlera, pp. 28-29.

25 PISM, A.45.299/3, School and Vocational Work Plans for Girls and for Boys of the Polish Centre in Barcelona for the school year 1950-1951, Barcelona, 16 October 1950 (in Polish).

26 PISM, A.45.299/3, Minute of the journey of Józef Tyszka, councillor of the Polish Legacy in Madrid, to Barcelona realized on 28-31 May 1950 (in Polish). 
dren whose parents or other relatives were unknown. Indeed, the government of the People's Poland, established in Warsaw, could demand their repatriation to Poland. However, if the children fell within the orbit of the IRO, their return to their country of origin would only be permitted if it was voluntary, regardless of their age. At the same time, the IRO took note and accepted the fact that the costs of caring for the Polish children in Barcelona was being covered by the Spanish government. ${ }^{27}$

\section{REPATRIATION OF A NUMBER OF CHILDREN FROM THE POLISH CENTRE IN BARCELONA}

Thanks to the efforts of the Central Tracing Bureau (CTB), an international organisation that searched for relatives lost during the World War II, some of the Polish children in Barcelona eventually found relatives from their homeland. In such cases, despite their critical attitude towards the political situation in Poland, the leaders of the Polish centre did not impede the repatriation of such children, as long as the child did not object to returning. On 1 January 1948, CTB's responsibilities were taken over by a new body acting under the auspices of the IRO - the International Tracing Service (ITS). ${ }^{28}$

In 1947, a total of 28 Polish children from Spain were transferred to the Polish Repatriation Mission in Paris, with the Representative of the Polish American Council in Geneva acting as intermediary. Because it was an American voluntary agency, the APWR as well as the American Polish Council (both of these institutions where represented in Europe by Florian Piskorski) could mediate between two parties who refused to acknowledge each other's existence - the Polish Legacy in Madrid (representing the government-in-exile) and the Polish Repatriation Mission in Paris (subordinate to the government in Warsaw). All 28 children left Barcelona on 30 October 1947. ${ }^{29}$ At the end of 1947, 73 Polish children remained in the Polish centre. ${ }^{30}$

27 PISM, Polish Legacy in Madrid (A.45).299/3, Letter: American Polish War Relief - Polish American Council to Relief Society for Poles in Barcelona, Geneva, 13 December 1948 (in Polish).

${ }_{28}$ About the International Tracing Service: P. Sęk ow ski, "Activity of the International Community in Europe after the Second World War within the Scope of the International Refugee Organization as a Model of the Aid Action towards Refugees," Securitologia 2017, no. 1, pp. 135-136.

29 PISM, PRM.E/135, Report on the Relief Society for Poles activities outside Great Britain in 1947, p. 58-59; Nens polonesos, pp. 184-188; M. Pernal, Barcelona, bon port, pp. 133-134 (in Catalan); 159 (in Spanish); 179 (in Polish).

30 PISM, PRM.E/135, Report on the Relief Society for Poles activities outside Great Britain in 1947, pp. 58-59. 
One year later (at the end of 1948), the total number of remaining children in the Catalan capital fell to $63-41$ boys and 22 girls. ${ }^{31}$ Ten children had been repatriated to Poland on 25 October 1948. ${ }^{32}$

In 1949, no child left the Polish centre in Barcelona. As a consequence, at the end of 194963 still remained in the centre, just as the year before..$^{33}$

On 19 August 1950, the final 11 children were repatriated to Poland. ${ }^{34}$ Their return was organised by the IRO, as in the meantime, i.e. during the first half of 1950 , the children from the Polish Centre had been placed under the IRO mandate. The IRO had assumed responsibility for completing the repatriation programme all around the world. In the case of Barcelona, it was The Joint that took care of this issue on behalf of IRO. ${ }^{35}$

Both in 1948 and 1950, the task of transferring the children into the care of Warsaw government agencies was handled by the Representative of the APWR. ${ }^{36}$

The total number of Polish children still in Barcelona after 19 August 1950 was 52-34 boys and 18 girls. ${ }^{37}$ No more repatriations to Poland occurred after this date.

\section{RESETTLEMENT OF POLISH CHILDREN FROM BARCELONA TO THE UNITED STATES OF AMERICA}

In April 1950, the Polish centre in Barcelona was visited by a Roman Catholic parish priest from Lackawanna (USA), Rev. Maksymilian Bogacki, who championed the idea of resettling some of the older Polish children in USA with the assistance of the NCWC. The rumours surrounding this plan caused a stir and some confusion inside the community. Putting the plan into practice would be problematic given the complex legal hurdles that first needed to be overcome, most importantly the fact that the Barcelona group still was not under IRO protection. Furthermore, news of this American project could have a negative impact on relations between the staff of the Polish centre (and representatives of the Polish government-in-exile in Spain as a whole) and the Spanish authorities. ${ }^{38}$

31 PISM, PRM.E/135, Report on the Relief Society for Poles activities outside Great Britain in 1948, p. 43; Nens polonesos, pp. 184-188.

32 Nens polonesos, pp. 184-188.

33 BPP, Mieczysław Biesiekierski Collection, provisional reference code: 3, Report on the Relief Society for Poles activities in 1949, p. 25, sheet 135; Nens polonesos, pp. 184-188.

${ }_{34}$ AN, AJ/43/310, Letter: Samuel Sequerra, American Joint Distribution Committee to IRO Headquarters, Barcelona, 23 June 1950 (in French); Nens polonesos, pp. 184-188.

${ }_{35}$ AN, AJ/43/310, Letter: Samuel Sequerra, American Joint Distribution Committee to IRO Headquarters.

36 M. Pernal, Barcelona, bon port, p. 135 (in Catalan); 159 (in Spanish); 179 (in Polish).

37 Nens polonesos, pp. 184-188.

38 PISM, A.45.299/3, Minute of the journey of Józef Tyszka, councillor of the Polish Legacy in Madrid, to Barcelona realized on 28-31 May 1950 (in Polish). 
However, the current guardians of the Polish children realized that their charges would have better life prospects in USA than in Francisco Franco's Spain in the 1950s where the economy was far poorer. In addition, decision-makers in the Polish émigré community were aware of the fact that the IRO would inevitably soon wind down its operations, and thus there was a danger that the children would waste an opportunity to emigrate overseas at the expense of the international community. The scheduled completion date for the IRO resettlement scheme was put back several times and was finally fixed for 1 February 1952.

For this reason, in the first half of 1950 the guardians of the Polish children in Barcelona began to step up their efforts to secure IRO protection - and thus guarantee them the status of "eligibles." ${ }^{39}$ Once "eligibility" under the IRO mandate had been secured, the way to overseas resettlement was open.

In 1951, two groups of Polish children left Barcelona for New York. The first group consisted of 8 children, while the second, which sailed from Gibraltar on 5 December 1951 on board of the ship Laguardia, comprised 22 children. All of them on reaching the USA were welcomed by the Polish community in Buffalo and were looked after by the Polish American Council. ${ }^{40}$ Altogether, in 1951 a total of 30 individuals from the Polish centre in Barcelona were resettled under the supervision of the IRO and their emigration registered within the IRO resettlement scheme.

The history of "the paradise that was Barcelona," as this period is described by many of the former residents of the Polish Centre, came to an end in July 1956 when the last 18 children emigrated to USA. On 23 July 1956, they flew from Lisbon to New York. Lisbon was chosen as the departure point because Portugal, unlike Spain, was a member of NATO, and an authorized country of last residence for refugees under the US Refugee Relief Act of $1953 .{ }^{41}$

In the meantime, between the end of 1951 and the middle of 1956, at least three children had left the Polish centre in Barcelona and made their way in the other direction than Poland or USA (see below in this paper). We say there were at least three, because we are unaware of the fate of one Polish child from Barcelona.

The final 18 charges of the Polish centre who emigrated to the United States in 1956 were no longer under the care of the IRO, as this agency had ceased to function in 1952. Hence, the children were sent to USA on a completely different legal basis - not as refugees dependent on the international community (and thus falling within the IRO mandate), but thanks to legislation enacted by the US Congress and an agreement concluded between USA and Portugal as a fellow NATO member.

Both in 1951 and in 1956, Florian Piskorski played a significant role in the overseas migration of the Polish children from Barcelona. This was thanks to his position as a representative of both the American Polish Council and the APWR. When at-

\footnotetext{
39 About the place of the resettlement in the activity of the IRO, see: P. Sękowski, "Activity of the International Community in Europe," pp. 132-135.

40 M. Pernal, Barcelona, bon port, p. 140 (in Catalan); 160 (in Spanish); 181 (in Polish); Nens polonesos, p. 184-188.

${ }^{41}$ M. Pernal, Barcelona, bon port, pp. 140-142 (in Catalan); 160-161 (in Spanish); 181-182 (in Polish).
} 
tempts were made to include these children within the IRO mandate in 1950, the applications were encouraged by the APWR as a voluntary agency officially accredited to the IRO. In turn, in 1956, Piskorki's extensive personal contacts, both in USA and in Portugal, also proved very valuable.

\section{POLISH CHILDREN FROM BARCELONA. FROM THE PERSPECTIVE OF APPLICATIONS FOR IRO ASSISTANCE}

A list of the Polish children who resided in Barcelona during the period examined was prepared and published in 2008 as part of a broader study of Poles in Barcelona, as was mentioned earlier. The table included in this study contains the first and last name of each child, their year of birth, the date of their arrival in Barcelona, the date of their departure from Barcelona and their subsequent destination (emigration to USA or repatriation to Poland). ${ }^{42}$ The author of the present paper will not repeat the results of these findings here. However, it is worth noting a few conclusions drawn from an analysis of the applications for IRO assistance filled in on behalf of the children by their guardians in the first half of 1950. All the applications were completed in English, a language which the vast majority of the children did not speak. Only in 2 of the 59 applications known to the author a slight knowledge of English were declared). Even if it is easy to realize that there were some conventions of answering the questions, the answers were provided in open-text fields (rather than the applicant being asked to choose from one of a limited number of options).

Until 1952, obtaining IRO protection was strictly required for overseas emigration, including for resettlement in the USA.

Moreover, as was mentioned above, the final repatriation of 11 Barcelona refugees to Poland in 1950 also took place under the auspices of the IRO, as in the meantime these children had been included under the mandate of this organization.

In the first half of 1950, 63 children were still living in the Polish centre in Barcelona. The archives of the IRO contain applications for IRO assistance for 59 children under the IRO mandate, including 48 children applying for resettlement and 11 children applying for repatriation. This means that no applications are found for 4 children. A comparison with the table featured in the publication mentioned above shows that the four missing individuals were young children, who in 1950 were aged between 6 and 9. All four left Barcelona in the last group of emigrants in 1956. It should be pointed out that one child was recorded in the IRO archives as a resident of the Polish centre in Barcelona in 1950, while according to the 2008 table this individual had left Spain in 1946 when the Polish centre was being established. Apart from this single case, the information gleaned from the IRO applications does not contradict the data contained in the table published in Polonsesos a Barcelona. ${ }^{43}$

42 Nens polonesos, pp. 184-188.

43 Comparison between $\mathrm{AN}, \mathrm{AJ} / 43 / 501$, Content of 48 applications for IRO assistance of children applying for overseas resettlement; $\mathrm{AN}, \mathrm{AJ} / 43 / 310$, Content of 11 applications for IRO assistance of chil- 


\section{Polish children from Barcelona requesting repatriation to Poland from the perspective of applications for IRO assistance}

In the case of the 11 children who intended to return to Poland, IRO applications were actually filled in twice: once on 28 April 1950 and once on 9 June 1950. Perhaps the reason why the process had to be repeated a second time was that the original applications had been filled out on outdated forms, which featured the name of the Preparatory Commission of the IRO (PC IRO - the former name of the IRO, changed in 1948). All the applications from April were signed by the children, while the "Signature of Interviewer" line was left empty in all cases. All the applications from June were signed by children while Wanda Morbitzer-Tozer's signature had been added to the "Signature of Interviewer."

In 1950, the children were aged between 12 and 19. All were Roman Catholic.

All the forms filled in April 1950 for children found in Austria after the World War II feature the same comment (or the same content, the same set of information) under the heading "Remarks. Use for any additional information":

- "I have been taken away from Poland under Himmler germanisation scheme and as the American Polish War Relief found my family I express herewith my desire to return to Poland."

In the forms filled in June 1950, under the heading "Do you wish to repatriate? If not, why?," the following answer was provided in all cases:

- "Yes I do, as the American Polish War Relief found my family in Poland, from which I have been taken away, and express herewith, my desire to return to Poland."

One interesting case concerns a boy who had been found in Nazi-occupied northeastern France where he had been living in 1941. The comments section in the form filled in April 1950 includes the declaration: "I have been taken away from Poland and as the American Polish War Relief found my family I express hereby my desire to return to Poland." There is no reference to the Germanization scheme. In turn, in the form filled in June 1950 under the heading "Under what circumstances did you leave your country" it is written: "I have been taken away from Poland with my parents to France."

In all 11 applications the same voluntary organizations are mentioned as providing care and assistance to the children: the Polish Red Cross in Austria and Italy, the Relief Society for Poles in Spain and the American Polish War Relief based in Geneva.

All the children came from pre-war Polish territories annexed to the Reich by the Nazi Germans. With the exception of the boy found in France, all the children were found in Austria. All 11 children were returned to a family member in Poland. ${ }^{44}$

dren applying for repatriation and $\mathrm{AN}, \mathrm{AJ} / 43 / 501$, Content of 11 renewed applications for IRO assistance of the same 11 children applying for repatriation and the table in Nens polonesos, pp. 184-188.

${ }_{44} \mathrm{AN}, \mathrm{AJ} / 43 / 310$, Content of 11 applications for IRO assistance of children applying for repatriation and $\mathrm{AN}, \mathrm{AJ} / 43 / 501$, Content of 11 renewed applications for IRO assistance of the same 11 children applying for repatriation. 
Table 1. Composition of the group of 11 children from Barcelona repatriated to Poland in August 1950

\begin{tabular}{|c|c|c|c|c|c|c|c|}
\hline \multicolumn{2}{|c|}{ Age } & \multicolumn{6}{|c|}{ Number of children by } \\
\hline & & Sex & Confession & $\begin{array}{c}\text { From } \\
\text { where } \\
\text { taken } \\
\text { away by } \\
\text { Nazi oc- } \\
\text { cupant }\end{array}$ & $\begin{array}{c}\text { Place of } \\
\text { residence } \\
\text { while } \\
\text { found } \\
\text { after the } \\
\text { war }\end{array}$ & $\begin{array}{c}\text { Relative } \\
\text { in Poland } \\
\text { to be } \\
\text { reunited }\end{array}$ & \\
\hline \multirow{6}{*}{\begin{tabular}{|c} 
Age \\
(birthday in rela- \\
tion to the end of \\
December 1950)
\end{tabular}} & 12 years old & 1 & & & & & \\
\hline & 14 years old & 1 & & & & & \\
\hline & 15 years old & 3 & & & & & \\
\hline & 16 years old & 4 & & & & & \\
\hline & 18 years old & 1 & & & & & \\
\hline & 19 years old & 1 & & & & & \\
\hline \multirow[t]{2}{*}{ Sex } & Male & & 7 & & & & \\
\hline & Female & & 4 & & & & \\
\hline \multirow[t]{2}{*}{ Confession } & Roman Catholic & & & 11 & & & \\
\hline & Other & & & 0 & & & \\
\hline \multirow{3}{*}{$\begin{array}{l}\text { From where } \\
\text { taken away by } \\
\text { Nazi occupant }\end{array}$} & Silesia & & & & 8 & & \\
\hline & Łódź & & & & 2 & & \\
\hline & $\begin{array}{c}\text { Former Polish } \\
\text { Warsaw province } \\
\text { but incorporated } \\
\text { into the Reich }\end{array}$ & & & & 1 & & \\
\hline \multirow{2}{*}{$\begin{array}{l}\text { Place of resi- } \\
\text { dence while } \\
\text { found } \\
\text { after the war }\end{array}$} & Austria & & & & & 10 & \\
\hline & France & & & & & 1 & \\
\hline \multirow{3}{*}{$\begin{array}{c}\text { Relative in Poland } \\
\text { to be reunited }\end{array}$} & Father/Mother & & & & & & 6 \\
\hline & Stepfather & & & & & & 1 \\
\hline & Uncle/Aunt & & & & & & 4 \\
\hline
\end{tabular}

Source: Own calculations of the author basing on: AN, AJ/43/310, Content of 11 applications for IRO assistance of children applying for repatriation, 28 April 1950 and AN, AJ/43/501, Content of 11 renewed applications for IRO assistance of the same 11 children applying for repatriation, 9 June 1950. 


\section{Polish children from Barcelona requesting resettlement from the perspective of the applications for IRO assistance}

The IRO archives include 48 applications for IRO assistance for children from the Polish centre in Barcelona who had applied for IRO protection and did not want to be repatriated to Poland. All the forms are dated 22 June 1950. All the forms were signed by the children and, with the exception of one application, Wanda Morbitzer-Tozer's signature appeared on the "Signature of Interviewer" line.

An analysis of the 45 applications for the resettlement of children provided protection under the IRO mandate revealed the following information.

In 1950, these children were aged between 8 and 22. All of them were Roman Catholic.

In all the forms filled out for the children found in Austria, as well as for the single child found in Germany, the same comment (or its equivalent) appears under the heading "Under what circumstances did you leave your country":

- "I have been taken away from Poland under Himmler germanisation scheme."

Under the heading "Do you wish to repatriate? If not, why?" the main reasons given for refusing to return to Poland were as follows :

- "I have no family in Poland,"

- "I don't agree with the present situation in Poland,"

- "I have no home in Poland."

The applications of all the children found in Austria as well as the 1 child found in Germany mention the same voluntary organizations as providing assistance: the Polish Red Cross in Austria and Italy, the Relief Society for Poles in Spain and the American Polish War Relief based in Geneva.

Most of the children applying for resettlement and provided protection under the IRO mandate came from territories annexed to the Reich - Silesia, Łódź and Warthegau - altogether 31 of the 45 children. Some of the children came from the Generalgouvernement, the occupied Polish territory not incorporated into the Reich. One child came from territory incorporated during the World War II into Reichskommissariat Ukraine. One child, already an orphan before the war, had been looked after by a resident of Western Pomerania (in pre-war Germany). Three children did not know their place of birth.

The majority were orphaned during the World War II and some even lost their parents in the pre-war period. Although some of the children had been in Germany for some time, almost all of them were in displaced persons camps in Austria when they were discovered by Polish officers. Only one child was found in Germany while another was found in France.

Interestingly, a considerable number of the children who did not want to return to Poland still had a family, i.e. 20 of the 45 children, three of whom had family only outside of Poland (but not in USA, where they wanted to emigrate).

Some of the charges of the Polish centre reached the age of majority during their stay in Barcelona. As the reason for their reluctance to return to Poland, they usually mentioned "the present situation in Poland" or "my political convictions." 
Among the other reasons that children with relatives gave for not wanting to be repatriated, were the following:

- "I have no home in Poland": "Father invalid, unable to take care of his son. He doesn't even answer letters,"

- "Father unable for the moment to take care of her": "now in touch with her father, but could not be repatriated due to her physical condition,"

- "My mother can't take care of me,"

- "My foster mother can't take care of me,"

- "His mother died." His father "refuses to recognise him as legitimate" (however, his younger brother and sister, twins, were repatriated to Poland the same year; probably his half-siblings),

Table 2. Composition of the group of 45 children from Barcelona to be resettled in USA - Applications for IRO assistance of June 1950

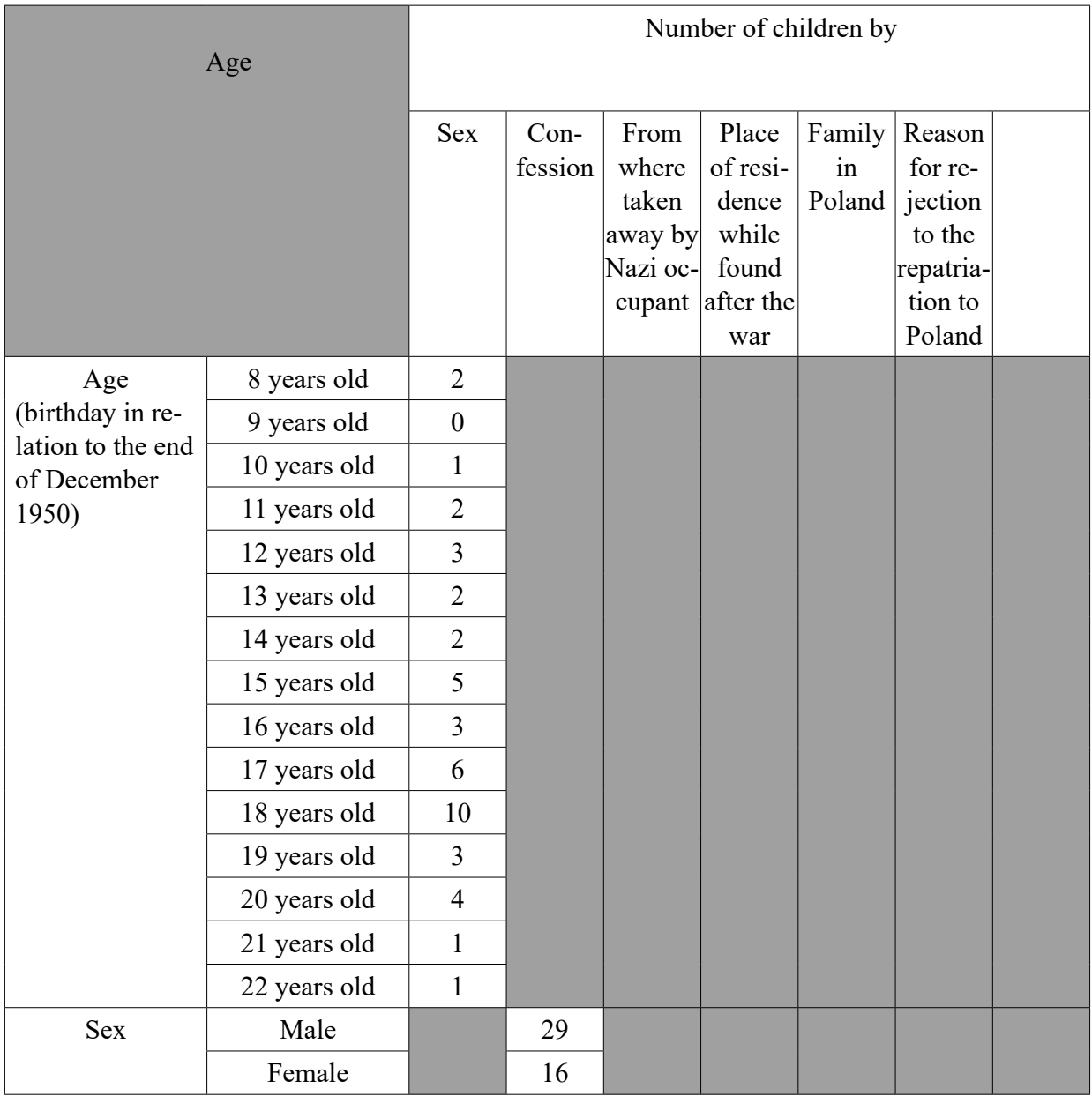




\begin{tabular}{|c|c|c|c|c|c|c|}
\hline \multirow[t]{2}{*}{ Confession } & Roman Catholic & 4 & & & & \\
\hline & Other & 0 & & & & \\
\hline \multirow{8}{*}{$\begin{array}{c}\text { From where } \\
\text { taken away } \\
\text { by Nazi } \\
\text { occupant }\end{array}$} & Silesia & & 17 & & & \\
\hline & Łódź & & 13 & & & \\
\hline & "Warthegau" & & 1 & & & \\
\hline & $\begin{array}{c}\text { Western } \\
\text { Pomerania }\end{array}$ & & 1 & & & \\
\hline & $\begin{array}{c}\text { "General } \\
\text { Governorate" }\end{array}$ & & 8 & & & \\
\hline & $\begin{array}{l}\text { Province Lviv } \\
\text { (today: Ukraine) }\end{array}$ & & 1 & & & \\
\hline & $\begin{array}{c}\text { Rovno, } \\
\text { Eastern Galicia } \\
\text { (today: Ukraine) }\end{array}$ & & 1 & & & \\
\hline & Unknown & & 3 & & & \\
\hline \multirow{3}{*}{$\begin{array}{c}\text { Place of } \\
\text { residence } \\
\text { while found } \\
\text { after the war }\end{array}$} & Austria & & & 43 & & \\
\hline & Germany & & & 1 & & \\
\hline & France & & & 1 & & \\
\hline \multirow[t]{2}{*}{ Family in Poland } & Yes & & & & 20 & \\
\hline & No & & & & 25 & \\
\hline \multirow{5}{*}{$\begin{array}{l}\text { Reason for the } \\
\text { desire of not be- } \\
\text { ing repatriated } \\
\text { to Poland }\end{array}$} & $\begin{array}{l}\text { "No family in } \\
\text { Poland" }\end{array}$ & & & & & 28 \\
\hline & $\begin{array}{l}\text { "No home in } \\
\text { Poland" }\end{array}$ & & & & & 3 \\
\hline & $\begin{array}{c}\text { Parent "can't take } \\
\text { care of me" }\end{array}$ & & & & & 6 \\
\hline & $\begin{array}{l}\text { "Present situation } \\
\text { in Poland"/“My } \\
\text { political convic- } \\
\text { tions" }\end{array}$ & & & & & 7 \\
\hline & $\begin{array}{l}\text { "Mother con- } \\
\text { sidered as pro- } \\
\text { German" }\end{array}$ & & & & & 1 \\
\hline
\end{tabular}

Source: Own calculations of the author basing on: AN, AJ/43/501, Content of 45 applications for IRO assistance of children applying for overseas resettlement who were recognized as within the mandate of the IRO, 22 June 1950. 
- "My nearest relative, sister Lucyna is unable to earn my living and take care of me" (this sister was in a convent),

- "I have no family in Poland": "Step-brother in Australia. Step-sister in England,"

- "I have no family in Poland. As my aunt apparently got Czech nationality, I don't wish either to join her in Czechoslovakia,"

- "He doesn't want to be in contact with his mother as she is considered by Polish authorities as pro-German."

Under the heading "Prospective employers or friends who might be of assistance to applicant" twelve boys, the youngest of whom was under 18 in mid-1950, gave the name of Rev. Maksymilian Bogacki from Lackawanna (New York) as a "sponsor."45

\section{THREE EXCEPTIONAL CASES OF POLISH CHILDREN FROM BARCELONA REQUESTING RESETTLEMENT FROM THE PERSPECTIVE OF THE APPLICATIONS FOR IRO ASSISTANCE}

Of the 59 applications for IRO assistance completed in June 1950, three stand out from the others.

One of these applications concerned a 17-year-old boy (in 1950), a Roman Catholic who was not even sure if he was a Polish citizen. What was known was that he was born in Italy. He was in Italy before the war and throughout the war years. His mother was a Pole and his father was Italian. After the war the boy did not have any contact with his father, and his mother had remarried a Pole and was living in England. In 1946, Polish officers included him, already in Italy, among the children, who were then transported to Barcelona. In the application for IRO assistance, he wrote:

- "I don't want to be repatriated to Poland as my mother is in England and I hope she'll be able to look after me in future."

In the case of this boy there was no question of repatriation to Poland. An IRO official wrote in the margin of the application form: "Not an unaccomp[anied] child as defined by IRO constit[ution]." The boy probably finally went to Great Britain. ${ }^{46}$

The other two unusual applications concern two brothers aged 17 and 19 in 1950. Both were born in France, were children of Polish immigrants and had lived throughout the war in their hometown. It was only in 1945 that they were placed in a camp for Polish displaced persons in France, and from there, as orphans, they were included among the Polish children from Austria that were transported to Barcelona. Their mother has died many years earlier and their father perished during the war. As the brothers did not have any family in Poland, they did not want to be repatriated. Although Rev. Maksymilian Bogacki was mentioned in the application of the elder

$45 \mathrm{AN}, \mathrm{AJ} / 43 / 501$, Content of 45 applications for IRO assistance of children applying for overseas resettlement who were recognized as within the mandate of the IRO, 22 June 1950.

46 AN, AJ/43/501, Application for IRO assistance of Antoni F., 22 June 1950. 
brother as a person who might be of assistance (as "sponsor"), IRO officials found both brothers ineligible for IRO protection, due to their age and specific wartime fate. ${ }^{47}$

\section{CONCLUSION}

Presented above is a history of the Polish centre in Barcelona in the years 19461956 together with an analysis of the protection provided for children under its care, with a particular emphasis on the applications for IRO assistance filled in 1950 by 59 Polish children. The information obtained from these sources deepens our understanding of the unusual fate of the more than 100 children who lived in this institution. It also sheds light on their family background and the reasons why they decided either to return to Poland, or refused to be repatriated and ultimately applied to emigrate to the United States of America.

The care and assistance provided for Polish children in Barcelona can be divided into the following three types, according to the status of the beneficiaries:

- care and assistance provided for displaced persons who wished to return to Poland,

- care and assistance for unaccompanied children, including efforts to trace their relatives,

- care and assistance for refugees who decided not to return to Poland and who desired to be resettled overseas (in USA).

The support provided for the Barcelona refugees came from both Polish émigré organizations that did not recognize the government of the Republic of Poland (since 1952: the People's Republic of Poland) in Warsaw, by the Spanish government as the host country, and by the international community. The main contribution of this paper lies in its description and highlighting of the role played by the IRO in supporting the children from the Polish centre in Barcelona.

\section{BIBLIOGRAPHY}

\section{Primary Sources}

Archives Nationales - Site de Pierrefitte sur Seine (AN)

Archives of the International Refugee Organization (AJ/43)

Archives of the Polish Institute and Sikorski Museum in London (PISM)

47 AN, AJ/43/501, Applications for IRO assistance of Marian Z. and Tadeusz Z., 22 June 1950. 
Embassy of the Republic of Poland in London - Political reports of Polish diplomatic offices (A.12.52).

Inner Cabinet [Prezydium Rady Ministrów], Eaton Place (PRM.E).

Bibliothèque polonaise de Paris (BPP)

Mieczysław Biesiekierski Collection

\section{Books and Articles}

Barbería, J. L., "Los niños que Hitler robó. Huérfanos de la barbarie nazi,” El País, 11 May 2008.

Bryant, T., Himmlers Kinder: Zur Geschichte der SS-Organisation „Lebensborn e.V.", Wiesbaden 2011.

Clay, C., Leapman, M., Master Race: The Lebensborn experiment in Nazi Germany, London 1995.

Dworski, A., "Hiszpania" [in:] Akcja niepodległościowa na terenie międzynarodowym, 1945-1990, ed. T. Piesakowski, Londyn 1999, pp. 342-354.

Gruzińska, A., "Children Remember the War: Polish Children in Barcelona, 1946-1956," The Polish Review 2010, vol. 55(1), pp. 111-122.

Habielski, R., Życie spoleczne i kulturalne emigracji, Warszawa 1999.

Holborn, L. W., The International Refugee Organization: A Specialized Agency of the United Nations. Its History and Work, London-New York-Toronto 1956.

Hrabar, R., ,Lebensborn”, czyli źródło życia, Katowice 1975.

Karpińska-Morek, E., Waś-Turecka, A., Sieradzka, M., Wróblewski, A., Majta, T., Drzonek, M., „,Teraz jesteście Niemcami”. Wstrząające losy zrabowanych polskich dzieci, Kraków 2018.

Lilienthal, G., Der „Lebensborn e.V.": Ein Instrument nationalsozialisticher Rassenpolitik, Frankfurt am Main 2003.

Nens polonesos que van viure els anys 1946-1956 a Barcelona = Niños polacos que vivian durante los años 1946-1956 en Barcelona = Dzieci polskie przebywające w latach 19461956 w Barcelonie [in:] Polonesos a Barcelona: Un munt d'històries: l'acolliment de la ciutat als nens robats pels nazis, 1946-1956 = Polacos en Barcelona, un montón de historias : la acogida de la ciudad a los niños robados por los nazis, 1946-1956=Polacy $w$ Barcelonie, album historii. Polskie dzieci ukradzione przez nazistów pod opieka miasta, 1946-1956, Barcelona 2008, pp. 184-188.

Pernal, M., Barcelona, bon port: Historia del cente d'acollida per a infants polonesos, 1946-1956 = Barcelona, buen Puerto: Historia del centro de acogida para niños polacos, 1946-1956 = Przystań Barcelona. Placówka opiekuńcza dla dzieci polskich $w$ stolicy Katalonii w latach 1946-1956 [in:] Polonsesos a Barcelona: Un munt d'històries: l'acolliment de la ciutat als nens robats pels nazis, 1946-1956 = Polacos en Barcelona, un montón de historias : la acogida de la ciudad a los niños robados por los nazis, 1946-1956 = Polacy w Barcelonie, album historii. Polskie dzieci ukradzione przez nazistów pod opieka miasta, 1946-1956, Barcelona 2008, p. 94-145 (in Catalan); 148-163 (in Spanish); 166-183 (in Polish).

Radomski, J. A., Demobilizacja Polskich Sit Zbrojnych na Zachodzie w latach 1945-1951, Kraków 2009. 
Sękowski, P., "Activity of the International Community in Europe after the Second World War within the Scope of the International Refugee Organization as a Model of the Aid Action towards Refugees," Securitologia 2017, no. 1, pp. 119-139.

Tarka, K., Emigracyjna dyplomacja. Polityka zagraniczna Rzadu RP na uchodźstwie, 19451990, Warszawa 2003. 